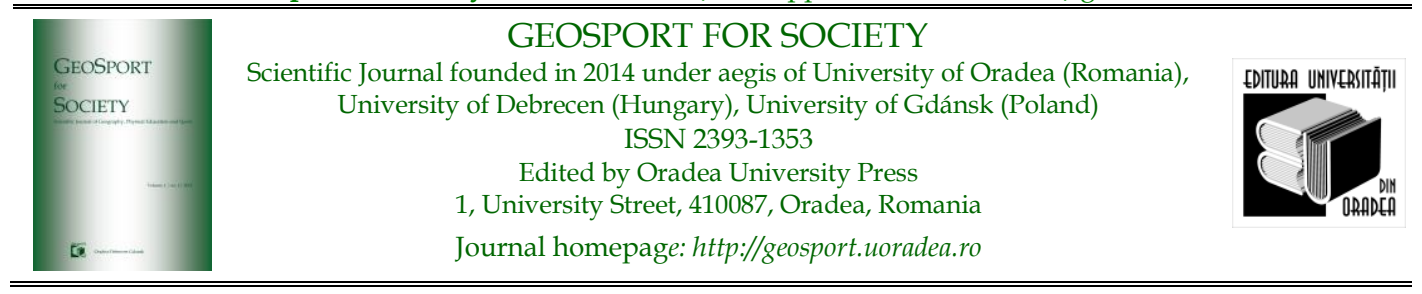

\title{
Aspects Regarding Geographic and Spatial Dispersion Determined by Romanian National Men's Basketball League (2006-2019)
}

\author{
Călin POP${ }^{1 *}$, Ioan FEFLEA², Marius MARINĂU²
}

1. University of Oradea, PH.D. School in Geography, 1 Universității st., cod 410087, Oradea, Romania, e-mails: pop calinbaschet@yahoo.com,

2. University of Oradea, Department of Physical Education, Sport and Physical Therapy, 1 Universității st., cod 410087, Oradea, Romania, e-mails: feflea@yahoo.com, marius marinau@yahoo.com

* Corresponding author

Citation: Pop, C., Feflea, I., \& Marinău, M. (2021). Aspects Regarding Geographic and Spatial Dispersion Determined by Romanian National Men's Basketball League (2006-2019). Geosport for Society, 14(1), 1-11. https://doi.org/10.30892/gss.1401-070

Article history: 18.01.2021; Revised: 15.02.2021; Accepted: 22.03.2021, Available online: 31.03 .2021

\begin{abstract}
This article intends to analyze the men's basketball phenomenon in Romania, at the level of the Romanian National Basketball League (the elite league in Romanian Men's Basketball). In the first part of this article we will analyze the numeric indicators resulted from the mathematical quantifiers of the participation of men's basketball teams in the National Basketball League. In the second part we will highlight aspects of geographic and spatial dispersion by using mathematical methods (such as the Euclidean distances). Furthermore, we will highlight the advantages and disadvantages of the geographic location of men's basketball teams from Romania.
\end{abstract}

Keywords: basketball, competitive season, Euclidean distances, geographic and spatial indicators

\section{Introduction}

"Space" and "Location" are central concepts in geography and sport. Places, for example, are means of identification of most sports teams, whereas sport impacts and is impacted by the physical environment and landscape where it takes place. Any quick analysis of sports phenomena would show that there are geographic and spatial differences from several perspectives, such as: the performance of sports clubs, the performance of athletes, the popularity of sports clubs or that of athletes, economic efficiency and many others. Naturally, these spatial differences vary according to the sports phenomenon that is being analyzed (Bale, 2003; Herman et al., 2018; Ilieș et al., 2014; Buhaș, 2015a; Ilieș et al., 2017; Buhaș, 2017). 
The analysis of the geographic dispersion of sports phenomena is a relatively new area of research; this analysis was carried out for the first time for economic activities, in order to study the effects of localization on business performance (using a series of indicators), economic growth, welfare, but also the impact of the location on the economy and the impact of economic activities on the location where these activities are being carried out. Based on this analysis, a lot of indicators which were valid in the analysis of economic activities, especially those that underscore geographic and spatial differences, were used to highlight geographic and spatial differences of sports phenomena.

There is also a geographic side to sport, since it has geographic features, models and movements. The geographic component is used for many aspects, from choosing the locations of sports fields to managing security during sports events.

Therefore, as far as sports events are concerned, there are two approaches used by the specialized literature in order to analyze sports phenomena from a geographic and spatial perspective: the first one focuses on the analysis of the impact determined by the spatial localization of sports clubs, whereas the second approach focuses on the analysis of the impact determined by the effects of sports phenomena on locations (Gratton et al., 2010; Herman et al., 2016, Doran and Declan, 2018; Buhaș, 2015b, c). We will use the first approach, analyzing the spatial localization of the men's basketball phenomenon in Romania. The second approach, regarding effects on locations, will explored in a future article.

\section{METHODOLOGY}

We have chosen the Romanian National Men's Basketball League (RNMBL) as basis for our analysis. The existing data that was used and analyzed in this study is taken from the 2006/2007-2018/2019 competitive seasons. This data, regarding participating teams, was provided by the Romanian Basketball Federation (https://www.frbaschet.ro/).

This study is structured in two parts: the first part is an analysis of the teams that took part in the RNMBL during the 2006/2007-2018/2019 competitive seasons, from a numeric and percentage perspective. In the second part, in order to identify spatial variability, Euclidean distances were calculated and analyzed (using the formula $\underline{\mathrm{d}=\sqrt{\left(x_{2}-x_{1}\right)^{2}+\left(y_{2}-y_{1}\right)^{2}}}$ where $\mathrm{x}$ and y were given by the eastern longitudinal values and, respectively, the northern latitude of each city which had at least one participating men's basketball team, for at least one competitive season between 2006-2019, as well as every participating team). In order to highlight the geographic and spatial distribution, the eastern longitudinal values and the northern latitudinal values were converted into Cartesian coordinates (Howard and Rorres, 1994).

\section{AREA OF STUDY, TEAMS, COMPETITIVE SEASONS}

During the 2006/2007-2018/2019 competitive seasons of the RNMBL, there were 30 participating professional teams, from 25 cities: Arad, Baia Mare, Brașov, Bucharest (four teams), Chiajna, Cluj-Napoca (three teams), Constanța, Craiova, Galați, Giurgiu, Iași, Mediaș, Miercurea Ciuc, Oradea, Otopeni, Pitești, Ploiești, 
Ploiești, Rm. Vâlcea, Sibiu, Târgoviște, Tg. Jiu, Tg. Mureș and Timișoara (two teams) (figure 1; table 1).

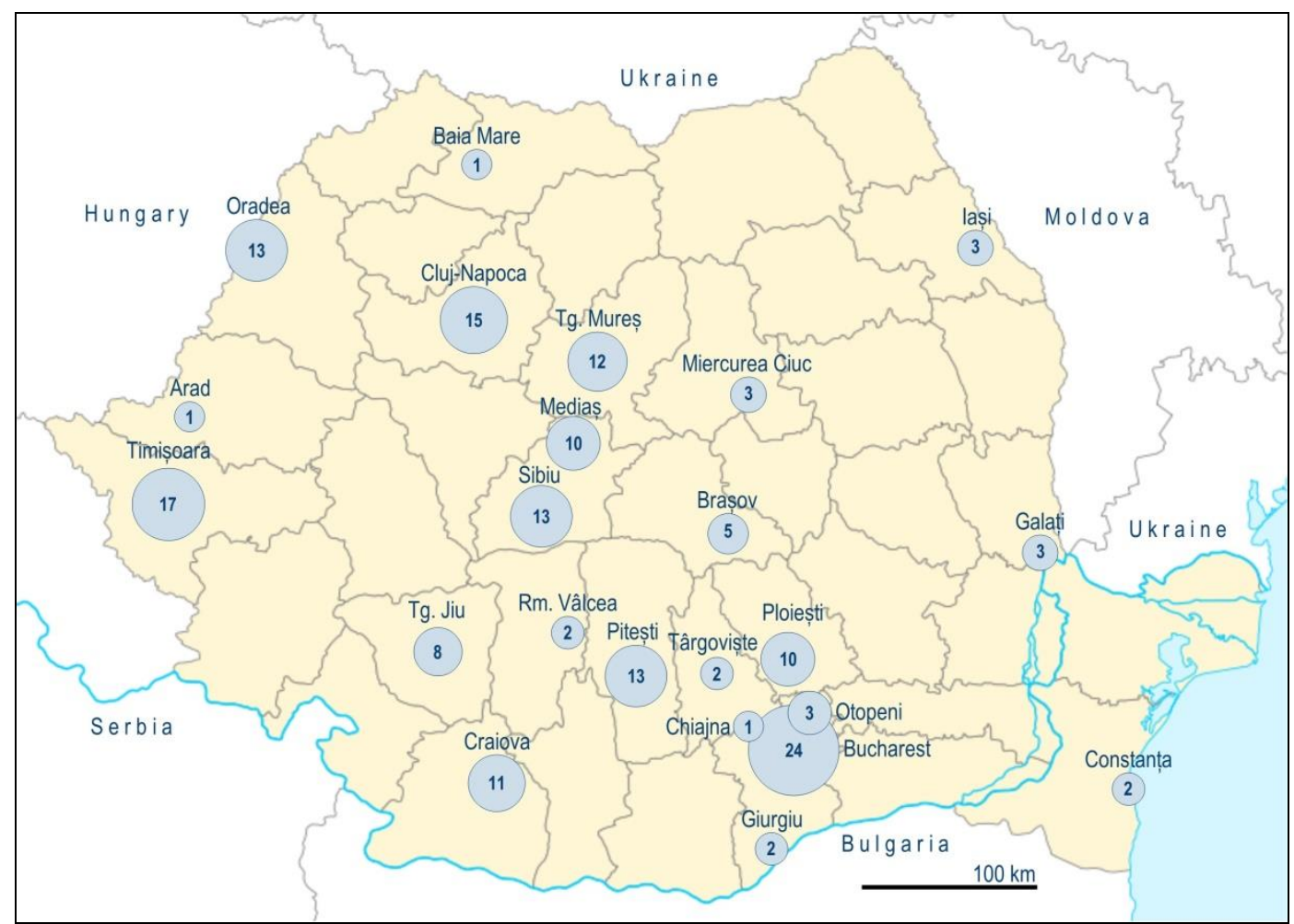

Figure 1. The intensity of the basketball phenomenon in the RNMBL during the 2006/20072018/2019 competitive seasons

(Source: The Romanian Basketball Federation and our own calculations)

Based on their attendance, the 30 teams that took part in the $2006 / 2007$ $2018 / 2019$ competitive seasons, in the RNMBL, can be classified into four categories (figure 1; table 1):

- Teams with the highest attendance score (with an attendance ranging between 75.1\% and 100\%): CS Dinamo Știința Bucharest (76.9\%), U BT Cluj-Napoca (100\%), SCMU Craiova (84.6\%), CS Gaz Metan Mediaș (76.9\%), CSM CSU Oradea (100\%), BCMU FC Argeș Pitești (100\%), CS CSU Sibiu (100\%), BC Mureș Tg. Mureș (92.3\%) and SCM Timișoara (100\%);

- Teams with a medium attendance score (ranging between $50.1 \%$ and $75 \%$ ): CSM Steaua CSM Eximbank Bucharest (61.5\%), CSU Asesoft Ploiești (69.2\%) and CS Energia Rovinari Tg. Jiu (61.5\%);

- Teams with a low attendance score (ranging between 25.1\% și 50\%): CSU Cuadripol Brașov (38.5\%), CS Otopeni (46.2\%) and BC Timba Timișoara (30.8\%) and

- Teams with a very low attendance score (inferior or equal to 25\%): West Petrom Arad (7.7\%), BCM Olimpia Baia Mare (7.7\%), Rapid Bucharest (23.1\%), CSM 
Bucharest (23.1\%), CS Concordia Chiajna (7.7\%), Gladiator Cluj-Napoca (7.7\%), Universitatea Cluj-Napoca (7.7\%), CS BC Farul Constanța (15.4\%), CS Phoenix Galați (23.1\%), CSȘ Giurgiu (15.4\%), CS Politehnica Iași (23.1\%), BC PH Csikszereda Miercurea Ciuc (23.1\%), CSM Ploiești (7.7\%), BC Rm. Vâlcea (15.4\%) and BC Gresiloft Târgoviște (15.4\%).

Table 1. The value of the Euclidean distances determined by the participating teams in the RNMBL in the 2006/2007-2018/2019 competitive seasons

(Data source: The Romanian Basketball Federation and our own calculations)

\begin{tabular}{|c|c|c|c|c|c|c|c|c|c|c|c|c|c|c|c|c|c|}
\hline \multirow[b]{2}{*}{ Cities } & \multirow{2}{*}{$\begin{array}{l}\text { Participating teams } \\
\text { in RNMBL }\end{array}$} & & & \multicolumn{14}{|c|}{ Competitive seasons } \\
\hline & & \begin{tabular}{|l} 
Num- \\
ber
\end{tabular} & $\%$ & \begin{tabular}{|c|}
$06 /$ \\
07 \\
\end{tabular} & \begin{tabular}{|c|}
$07 /$ \\
08 \\
\end{tabular} & \begin{tabular}{|l|}
$08 /$ \\
09 \\
\end{tabular} & \begin{tabular}{|c|}
$09 /$ \\
10 \\
\end{tabular} & \begin{tabular}{|l|}
$10 /$ \\
11 \\
\end{tabular} & \begin{tabular}{|c|}
$11 /$ \\
12 \\
\end{tabular} & \begin{tabular}{|c|}
$12 /$ \\
13 \\
\end{tabular} & \begin{tabular}{|c|}
$13 /$ \\
14 \\
\end{tabular} & \begin{tabular}{|c|}
$14 /$ \\
15 \\
\end{tabular} & $\begin{array}{l}15 / \\
16 \\
\end{array}$ & \begin{tabular}{|c|}
$16 /$ \\
17 \\
\end{tabular} & \begin{tabular}{|c|}
$17 /$ \\
18 \\
\end{tabular} & \begin{tabular}{|c|}
$18 /$ \\
19 \\
\end{tabular} & $\begin{array}{l}\text { Ave- } \\
\text { rage }\end{array}$ \\
\hline Arad & West Petrom & 1 & $7.7 \%$ & 3.43 & & & & & & & & & & & & & 3.43 \\
\hline Baia Mare & BCM Olimpia & 1 & $7.7 \%$ & & & & & & & & & & & 2.94 & & & 2.94 \\
\hline Brașov & CSU Cuadripol & 5 & $38.5 \%$ & 2.01 & 1.74 & 1.85 & 1.91 & 1.93 & & & & & & & & & 1.89 \\
\hline \multirow{4}{*}{ Bucharest } & CS Dinamo Știința & 10 & $76.9 \%$ & 2.39 & 2.06 & 2.15 & 2.18 & & 2.24 & 2.53 & & & 2.68 & 2.62 & 2.94 & 2.77 & 2.46 \\
\hline & CSM Steaua CSM Eximbank & 8 & $61.5 \%$ & & & & 2.18 & 2.45 & & & 2.74 & 3.03 & 2.68 & 2.62 & 2.94 & 2.77 & 2.68 \\
\hline & Rapid & 3 & $23.1 \%$ & 2.39 & 2.06 & 2.15 & & & & & & & & & & & 2.20 \\
\hline & CSM & 3 & $23.1 \%$ & & & & 2.18 & & 2.24 & 2.53 & & & & & & & 2.32 \\
\hline Chiajna & CSConcordia & 1 & $7.7 \%$ & & & & & & & & 2.65 & & & & & & 2.65 \\
\hline \multirow{3}{*}{ Cluj-Napoca } & UBT & 13 & $100.0 \%$ & 2.25 & 2.26 & 2.27 & 2.18 & 2.29 & 2.46 & 2.52 & 2.45 & 1.90 & 2.29 & 2.40 & 2.65 & 2.42 & 2.33 \\
\hline & Gladiator & 1 & $7.7 \%$ & & & & 2.18 & & & & & & & & & & 2.18 \\
\hline & Universitatea & 1 & $7.7 \%$ & & & & & & & & & 1.90 & & & & & 1.90 \\
\hline Constanța & CSBCFarul & 2 & $15.4 \%$ & & & & & & & 4.69 & 4.94 & & & & & & 4.82 \\
\hline Craiova & SCMU & 11 & $84.6 \%$ & & & 2.13 & 2.19 & 2.38 & 2.37 & 2.42 & 2.40 & 2.21 & 2.32 & 2.58 & 2.77 & 2.29 & 2.37 \\
\hline Galați & CSPhoenix & 3 & $23.1 \%$ & & & & & & & & & & 4.16 & 4.02 & 4.16 & & 4.11 \\
\hline Giurgiu & CSȘ & 2 & $15.4 \%$ & & & & & & 2.52 & 2.75 & & & & & & & 2.64 \\
\hline Iași & CSPolitehnica & 3 & $23.1 \%$ & & & & & 3.77 & 3.80 & & & & & & 4.16 & & 3.91 \\
\hline Medias & CSGaz Metan & 10 & $76.9 \%$ & 1.85 & 1.72 & 1.77 & 1.77 & 1.82 & 1.96 & 2.10 & 2.09 & 1.76 & 1.92 & & & & 1.88 \\
\hline Miercurea Ciuc & BC PHCsikszereda & 3 & $23.1 \%$ & & & & & 2.19 & 2.29 & 2.58 & & & & & & & 2.35 \\
\hline Oradea & CSMCSU & 13 & $100.0 \%$ & 3.24 & 3.47 & 3.41 & 3.35 & 3.45 & 3.63 & 3.51 & 3.35 & 2.76 & 3.33 & 3.45 & 3.52 & 3.23 & 3.36 \\
\hline Otopeni & CS & 6 & $46.2 \%$ & 2.33 & 1.99 & 2.09 & 2.13 & 2.37 & 2.19 & & & & & & & & 2.18 \\
\hline Pitești & BCMU FC Argeș & 13 & $100.0 \%$ & 1.88 & 1.63 & 1.68 & 1.77 & 1.92 & 1.91 & 2.09 & 2.16 & 2.11 & 2.06 & 2.17 & 2.45 & 2.10 & 1.99 \\
\hline Ploiești & CSU Asesoft & 9 & $69.2 \%$ & 2.21 & 1.88 & 1.99 & 2.05 & 2.21 & 2.19 & 2.41 & 2.58 & 2.78 & & & & & 2.26 \\
\hline Ploiești & CSM & 1 & $7.7 \%$ & & & & & & & & & & & 2.45 & & & 2.45 \\
\hline Rm. Vâlcea & $\mathrm{BC}$ & 2 & $15.4 \%$ & 1.83 & 1.66 & & & & & & & & & & & & 1.75 \\
\hline Sibiu & $\mathrm{BCCSU}$ & 13 & $100.0 \%$ & 1.79 & 1.69 & 1.71 & 1.72 & 1.81 & 1.93 & 2.04 & 2.01 & 1.68 & 1.85 & 2.07 & 2.31 & 2.01 & 1.89 \\
\hline Târgoviște & BCGresiloft & 2 & $15.4 \%$ & & 1.65 & 1.74 & & & & & & & & & & & 1.70 \\
\hline Tg.jiu & CSEnergia & 8 & $61.5 \%$ & & & 2.10 & 2.13 & 2.29 & 2.36 & 2.36 & 2.27 & 1.92 & 2.19 & & & & 2.20 \\
\hline Tg.Mureș & BC Mureș & 12 & $92.3 \%$ & 2.00 & 1.89 & 1.96 & 1.94 & 1.95 & 2.11 & 2.27 & 2.29 & 1.96 & 2.11 & 2.23 & 2.49 & & 2.10 \\
\hline \multirow{2}{*}{ Timișoara } & SCM & 13 & $100.0 \%$ & 3.48 & 3.78 & 3.65 & 3.63 & 3.77 & 3.91 & 3.64 & 3.45 & 2.91 & 3.58 & 3.81 & 3.68 & 3.40 & 3.59 \\
\hline & BC Timba & 4 & $30.8 \%$ & & & & & & & 3.64 & 3.45 & 2.91 & & & \begin{tabular}{|l|}
3.68 \\
\end{tabular} & & 3.42 \\
\hline \multicolumn{2}{|c|}{ Total attendance in RNMBL } & & & 14 & 14 & 15 & 16 & 15 & 16 & 16 & 14 & 13 & 12 & 12 & 12 & 8 & \\
\hline \multicolumn{2}{|r|}{ Average } & & 117 & & 2.11 & 2.18 & 2.22 & 2.44 & 2.51 & 2.76 & 2.77 & 2.29 & 2.60 & 2.78 & 3.15 & 2.62 & 2.60 \\
\hline
\end{tabular}

During the competitive seasons that are being analyzed, the Romanian National Men's Basketball League held 13 championships, one per every competitive year. Therefore, during this period the maximum number of participating teams, 16, was reached in the following competitive seasons: 2009/2010, 2011/2012 and $2012 / 2013$. If in the first part of the period of time that is being analyzed, the number of participating teams ranged between 14 and 16, in the second part of the same period, there was a decrease with every season; in the 2012-2013 competitive 
season there were 16 participating teams, whereas in the $2018 / 2019$ competitive season the number dropped to 8 (figure 2; table 1).

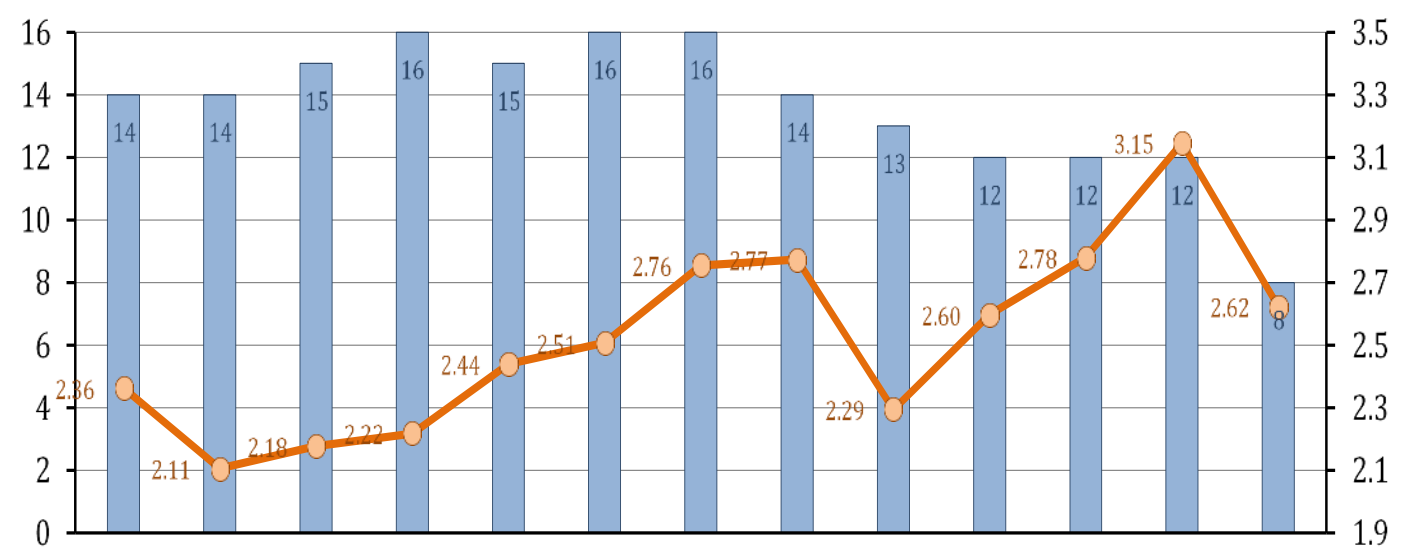

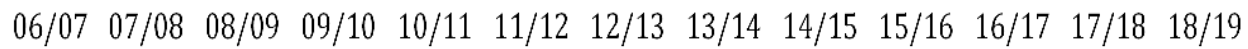

$\square$ Number of teams participating in the National Men's Basketball League $-\mathrm{O}=$ Average of the euclidean distances

Figure 2. The number of participating teams in the RNMNL and the average of Euclidean distances for the 2006/2007-2018/2019 competitive seasons

(Data source: The Romanian Basketball Federation and our own calculations)

\section{ANALYSIS OF THE GEOGRAPHIC AND SPATIAL DISPERSION 2006/2007 Competitive Season}

There were 14 participating teams in the RNMBL, in the 2006/2007 competitive season. The average distance covered by a team during the 2006/2007 season, calculated according to the Euclidean distances, was 2.36; the average minimum distance was 1.79 (covered by BC CSU Sibiu), and the average maximum distance was 3.48 (covered by SCM Timișoara) (figures 2, 3; table 1).

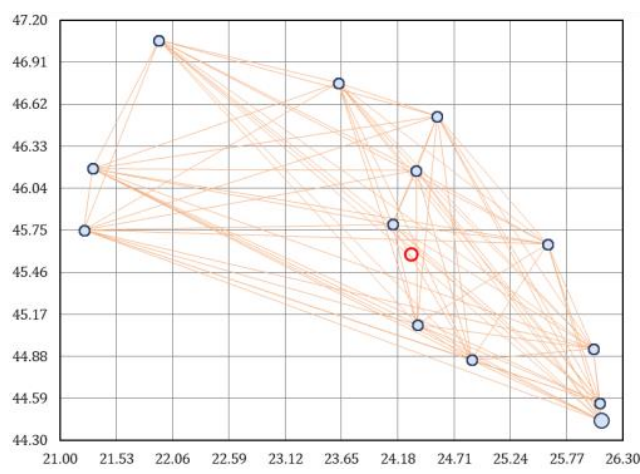

Figure 3. The Euclidean distance system for the 2006/2007 competitive season

(Data source: The Romanian Basketball Federation and our own calculations)

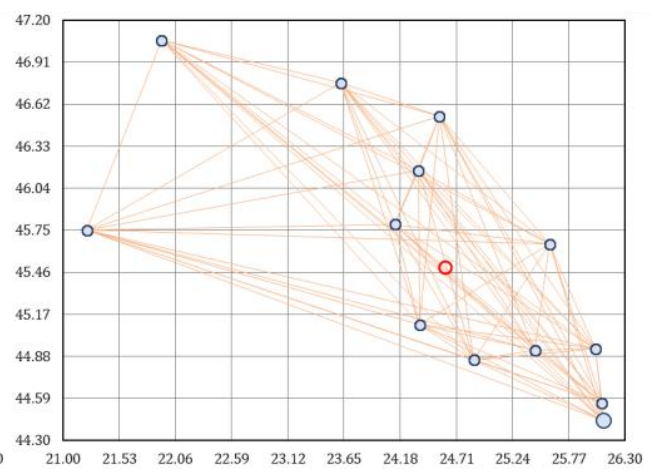

Figure 4. The Euclidean distance system for the 2007/2008 competitive season

(Data source: The Romanian Basketball Federation and our own calculations) 


\section{7/2008 Competitive Season}

In the $2007 / 2008$ competitive season, there were also 14 teams in RNMBL. The average distance covered by a team during the 2007/2008 season, calculated using the Euclidean distances, was 2.11 (12.2\% less than the previous competitive season); the average minimum distance was 1.63 (covered by BCMU FC Argeș Pitești) and the average maximum distance was 3.78 (covered by SCM Timișoara) (figures 2, 4; table 1).

\section{8/2009 Competitive Season}

There were 15 participating teams in the RNMBL, in the 2008/2009 competitive season (one team more than the previous competitive season) The average distance covered by a team during the 2008/2009 season, calculated according to the Euclidean distances, was 2.18 (3.3\% more than the previous competitive season); the average minimum distance was 1.68 (covered by BCMU FC Argeș Pitești), and the average maximum distance was 3.65 (covered by SCM Timișoara) (figures 2, 5; table 1).

\section{9/2010 Competitive Season}

There were 16 participating teams in the RNMBL, in the 2009/2010 competitive season (one team more than the previous competitive season) The average distance covered by a team during the 2009/2010 season, calculated according to the Euclidean distances, was 2.22 (1.9\% more than the previous competitive season); the average minimum distance was 1.72 (covered by BC CSU Sibiu), and the average maximum distance was 3.63 (covered by SCM Timișoara) (figures 2, 6; table 1).

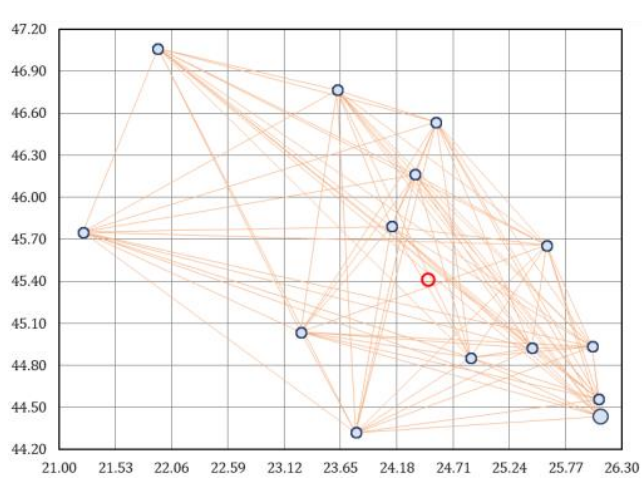

Figure 5. The Euclidean distance system for the 2008/2009 competitive season

(Data source: The Romanian Federation and Basketball our own calculations)

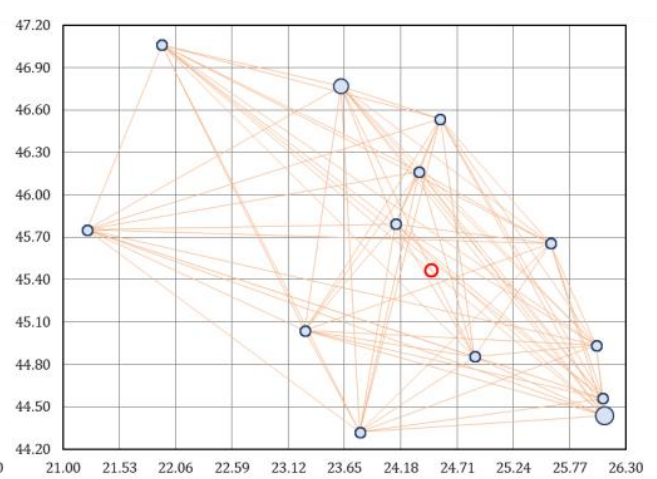

Figure 6. The Euclidean distance system for the 2009/2010 competitive season

(Data source: The Romanian Basketball Federation and our own calculations)

\section{0/2011 Competitive Season}

There were 15 participating teams in the RNMBL, in the 2010/2011 competitive season (one team less than the previous competitive season). The average distance covered by a team during the 2010/2011 season, calculated 
according to the Euclidean distances, was 2.44 (9.1\% more than the previous competitive season); the average minimum distance was 1.81 (covered by BC CSU Sibiu), and the average maximum distance was 3.77 (covered by SCM Timișoara) (figures 2, 7; table 1).

\section{1/2012 Competitive Season}

There were 16 participating teams in the RNMBL, in the 2011/2012 competitive season (one team more than the previous competitive season). The average distance covered by a team during the 2011/2012 season, calculated according to the Euclidian distances, was 2.51 (2.7\% more than the previous competitive season); the average minimum distance was 1.91 (covered by BCMU FC Argeș Pitești), and the average maximum distance was 3.91 (covered by SCM Timișoara) (figures 2, 8; table 1).

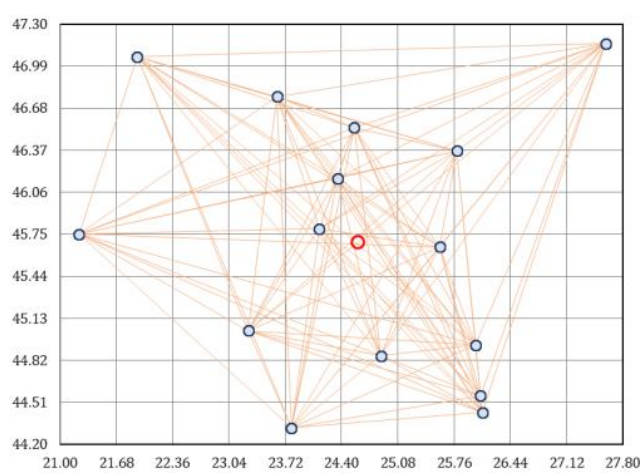

Figure 7. The Euclidean distance system for the 2010/2011 competitive season

(Data source: The Romanian Federation and Basketball our own calculations)

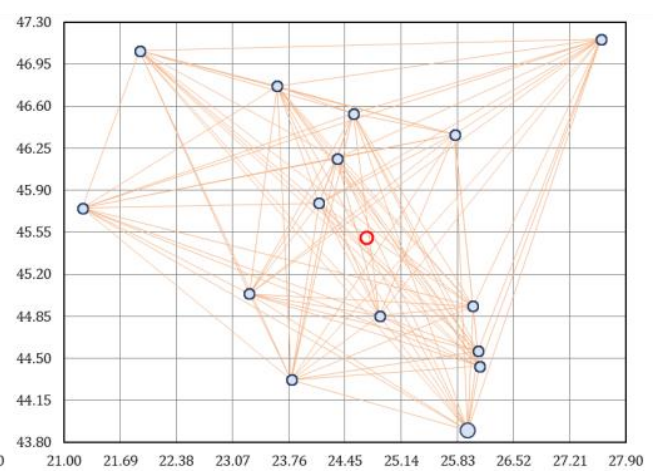

Figure 8. The Euclidean distance system for the 2011/2012 competitive season

(Data source: The Romanian Basketball Federation and our own calculations)

\section{2/2013 Competitive Season}

In the $2007 / 2008$ competitive season, there were also 16 teams in RNMBL. The average distance covered by a team during the 2012/2013 season, calculated according to the Euclidean distances, was 2.76 (9.0\% more than the previous competitive season); the average minimum distance was 2.04 (covered by BC CSU Sibiu) and the average maximum distance was 4.69 (covered by CS BC Farul Constanța) (figures 2, 9; table 1).

\section{3/2014 Competitive Season}

In this season, the number of participating teams dropped to 14 in RNMBL (two teams less than in the previous competitive season). The average distance covered by a team during the $2013 / 2014$ season, calculated according to the Euclidean distances, was 2.77 (0.7\% more than the previous competitive season); the average minimum distance was 2.01 (covered by BC CSU Sibiu) and the average maximum distance was 4.94 (covered by CS BC Farul Constanța) (figures 2, 10; table 1). 


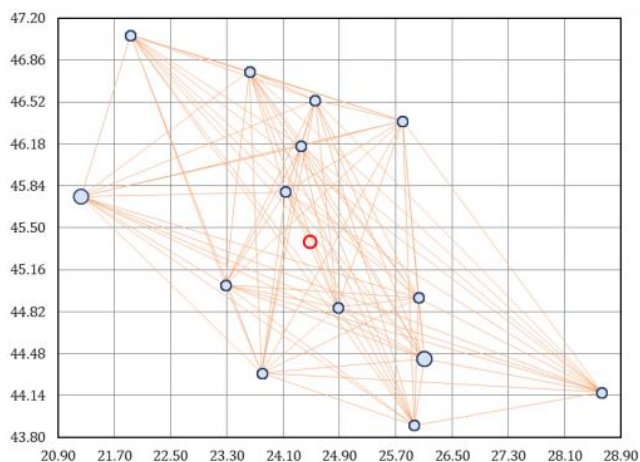

Figure 9. The Euclidean distance system for the 2012/2013 competitive season

(Data source: The Romanian Federation and Basketball our own calculations)

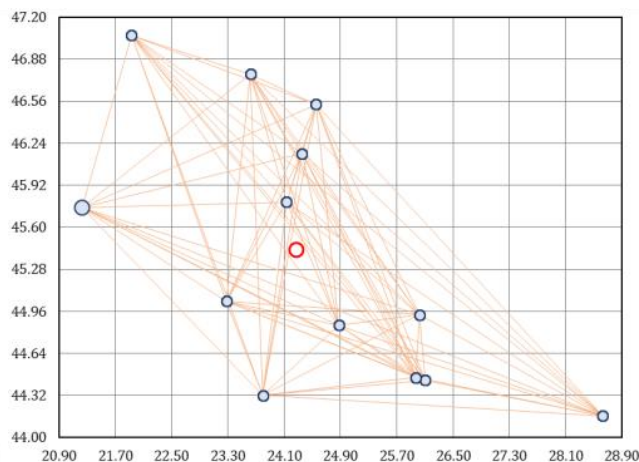

Figure 10. The Euclidean distance system for the 2013/2014 competitive season

(Data source: The Romanian Basketball Federation and our own calculations)

\section{4/2015 Competitive Season}

There were 13 participating teams in the RNMBL, in the 2014/2015 competitive season (one team less than the previous competitive season). The average distance covered by a team during the 2014/2015 season, calculated according to the Euclidean distances, was 2.29 (20.9\% less than the previous competitive season); the average minimum distance was 1.68 (covered by BC CSU Sibiu), and the average maximum distance was 3.03 (covered by CSM Steaua CSM Eximbank Bucharest) (figures 2, 11; table 1).

\section{5/2016 Competitive Season}

There were 12 participating teams in the RNMBL, in the 2015/2016 competitive season (one team less than the previous competitive season). The average distance covered by a team during the 2015/2016 season, calculated according to the Euclidean distances, was 2.60 (11.7\% more than the previous competitive season); the average minimum distance was 1.85 (covered by BC CSU Sibiu), and the average maximum distance was 4.16 (covered by CS Phoenix Galați) (figures 2, 12; table 1).

\section{6/2017 Competitive Season}

There were also 12 participating teams in the RNMBL, in the 2016/2017 competitive season. The average distance covered by a team during the 2016/2017 season, calculated according to the Euclidean distances, was 2.78 (6.6\% more than the previous competitive season); the average minimum distance was 2.07 (covered by BC CSU Sibiu), and the average maximum distance was 4.02 (covered by CS Phoenix Galați) (figures 2, 13; table 1).

\section{7/2018 Competitive Season}

There were also 12 participating teams in the RNMBL, in the $2017 / 2018$ competitive season. The average distance covered by a team during the $2017 / 2018$ season, calculated according to the Euclidean distances, was 3.15 (11.6\% more than 
the previous competitive season); the average minimum distance was 2.31 (covered by BC CSU Sibiu), and the average maximum distance was 4.16 (covered by CS Politehnica Iași) (figures 2, 14; table 1).

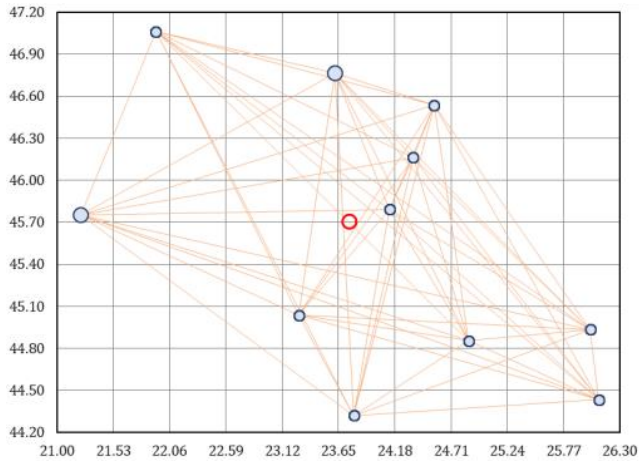

Figure 11. The Euclidean distance system for the 2014/2015 competitive season (Data source: The Romanian Federation and Basketball our own calculations)

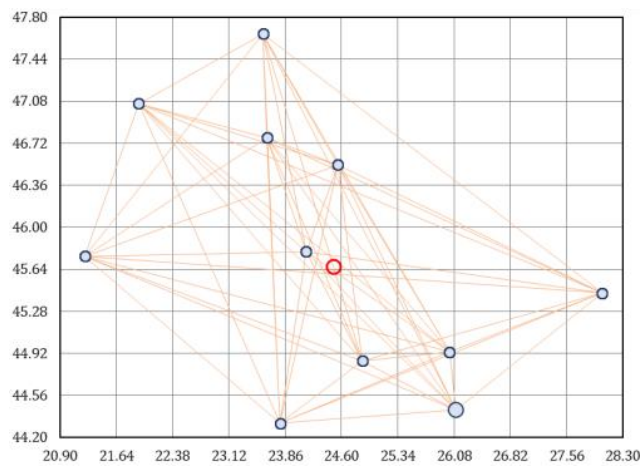

Figure 13. The Euclidean distance system for the 2016/2017 competitive season (Data source: The Romanian Federation and Basketball our own calculations)

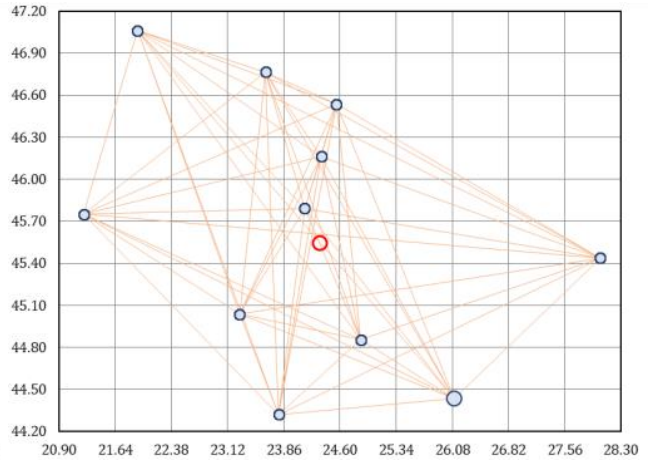

Figure 12. The Euclidean distance system for the 2015/2016 competitive season

(Data source: The Romanian Basketball Federation and our own calculations)

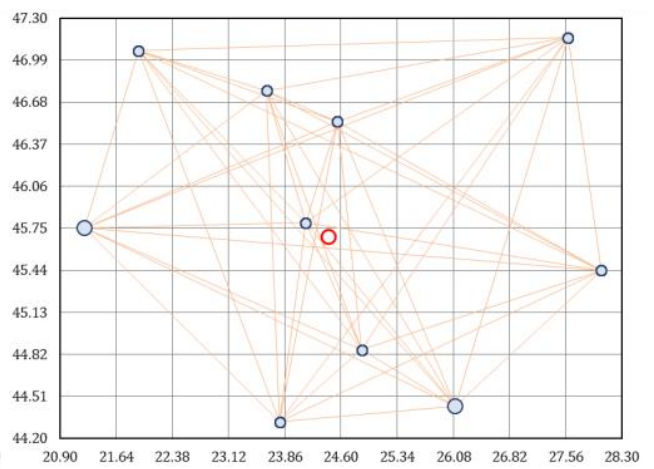

Figure 14. The Euclidean distance system for the $2017 / 2018$ competitive season

(Data source: The Romanian Basketball Federation and our own calculations)

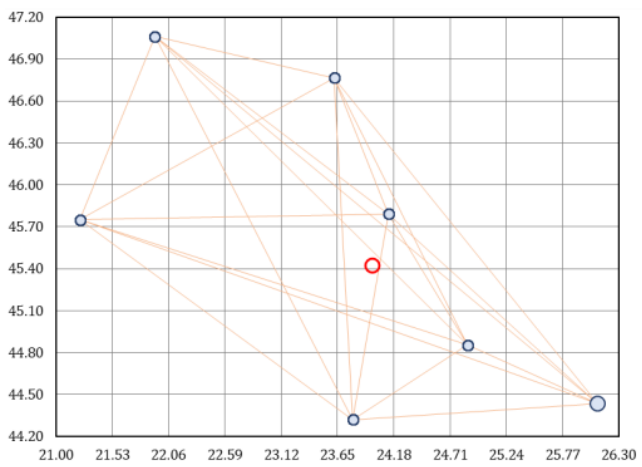

Figure 15. The Euclidean distance system for the 2018/2019 competitive season (Data source: The Romanian Federation and Basketball our own calculations) 


\section{8/2019 Competitive Season}

There were 8 participating teams in the RNMBL, in the 2018/2019 competitive season (four teams less than the previous competitive season). The average distance covered by a team during the 2018/2019 season, calculated according to the Euclidean distances, was $2.62(19.9 \%$ less than the previous competitive season); the average minimum distance was 2.01 (covered by BC CSU Sibiu), and the average maximum distance was 3.40 (covered by SCM Timișoara). (figures 2, 15; table 1).

The competitive centre of gravity of the RNMBL is represented by the average between the eastern longitudinal and northern latitudinal values of each city that has had at least a participating men's basketball team, for at least a competitive season, calculated for each season in part. Values that vary from one season to the other are determined by the changes that occurred at a competitive level (figure 16).
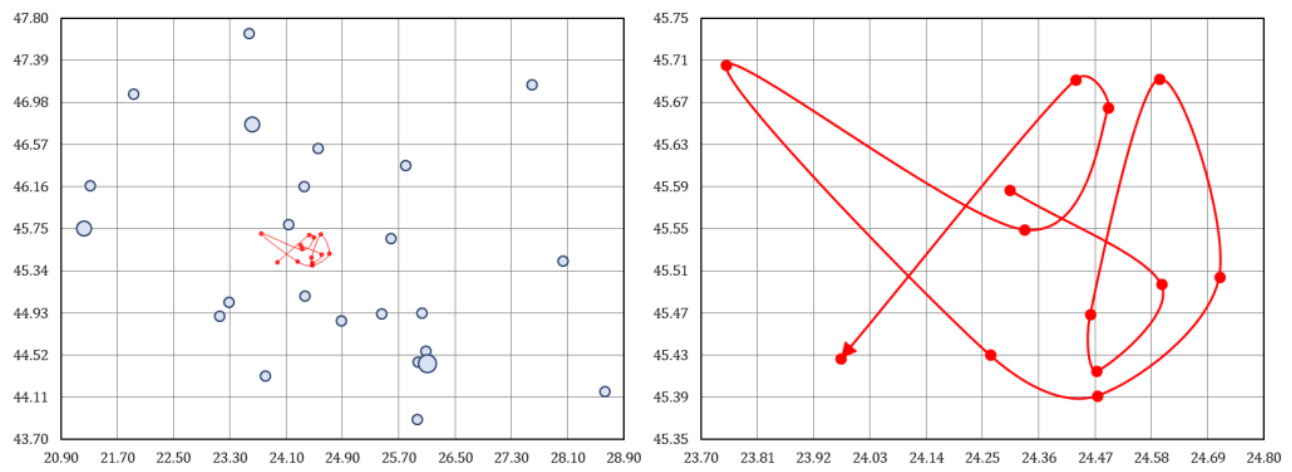

Figure 16. The competitive centre of gravity of the RNMBL for the 2006/2007-2018/2019 competitive seasons

(Data source: The Romanian Federation and Basketball our own calculations)

\section{CONCLUSION}

By observing the number of participating teams in the Romanian National Men's Basketball League and the evolution of the average of the Euclidean distances, we can assert that there is no relation of proportionality between these two aspects (figure 2).

Based on the analysis of the Euclidean distances determined by the position of the cities that have men's basketball teams and the competitive centre of gravity, we can set up the following classification (figures 3-15; table 1):

- Close teams, $(73.3 \%$ out of the total number of teams, with an average distance ranging between 1.70 and 2.73): CSU Cuadripol Brașov (1.89), CS Dinamo Știința Bucharest (2.46), CSM Steaua CSM Eximbank Bucharest (2.68), Rapid Bucharestt (2.20), CSM Bucharest (2.32), CS Concordia Chiajna (2.65), U BT ClujNapoca (2.33), Gladiator Cluj-Napoca (2.18), Universitatea Cluj-Napoca (1.90), SCMU Craiova (2.37), CSȘ Giurgiu (2.64), CS Gaz Metan Mediaș (1.88), BC PH Csikszereda Miercurea Ciuc (2.35), CS Otopeni (2.18), BCMU FC Argeș (1.99), CSU Asesoft Ploiești (2.26), CSM Ploiești (2.45), BC Rm. Vâlcea (1.75), BC CSU Sibiu (1.89), BC Gresiloft 
Târgoviște (1.70 -the lowest value), CS Energia Rovinari Tg. Jiu (2.20) and BC Mureș Tg. Mureș (2.10);

- Distant teams, $(16.7 \%$ out of the total number of teams, with an average distance ranging between 2.74 and 3.77): West Petrom Arad (3.43), BCM Olimpia Baia Mare (2.94), CSM CSU Oradea (3.36), SCM Timișoara (3.59) and BC Timba Timișoara (3.42) and

- Very distant teams, $(10.0 \%$ out of the total number of teams, with an average distance ranging between 3.78 and 4.82): CS BC Farul Constanța (4.82 - the highest value), CS Phoenix Galați (4.11) and CS Politehnica Iași (3.91).

In conclusion, observing the distribution hereinbefore, we can assert that, at least from the point of view of the geographic location, the teams situated in peripheral cities in relation to the national territory are considered to be distant or very distant from the competitive centre of gravity determined by the basketball phenomenon in Romania.

\section{References}

Bale, J.R. (2003). Sports Geography, Routledge, London.

Buhaș, D. S., Herman, G. V., Paul, F. D., \& Stance, L. (2017). Football and economy before and after communism in Romania. GeoSport for Society, 6(1), 30-39

Buhaș, S. D. (2015a). Sport management. From institutionalism to research. Geosport for Society, 2(1), 26-32.

Buhaș, S. D. (2015b). Managementul organizaţiilor sportive [The management of sports organizations], Eikon Publishing House, Cluj Napoca (in Romanian).

Buhaș, S. D. (2015c). Strategii manageriale, cluburile de fotbal din liga 1 [Management strategies. Football clubs in League I], Eikon Publishing House, Cluj Napoca (in Romanian).

Doran, J., \& Declan, J. (2018). The effect of geographical proximity and rivalry on performance: evidence from the English Football League. Regional Studies, 52(11), 1559-1569.

Gratton, C., Bobson, N., \& Shibil, S. (2000). The economic importance of major sports events: a casestudy of six events. Managing Leisure, 5(1), 17-28.

Herman, G.V., Buhaș, S.D., Stance, L., Pop, C.A. (2016). Considerations regarding the evolution, distribution and dynamics of the romanian football (League I) between 1989-2016. GeoSport for Society, 5(2), 69-78.

Herman, G.V., Szabo-Alexi, Mariana, Szabo-Alexi, P., Dragoș, F.P., Marinău, M. (2018). The sport, vector of regionalization / globalization Case study: International Volleyball Federation (FIVB). GeoSport for Society, 9(2), 88-95.

Howard, A., \& Rorres, C. (1994). Elementary Linear Algebra (11th ed.). Wiley. pp. 131-182.

Ilieș, A., (coord.), Baias, Ș., Baias, I., Blaga, L., Buhaș, S., Chiriac, A., Ciocan, J., Dăncuș, M., Deac, A., Dragoș, P., Dumitrescu, G., Gaceu, O., Godea, I., Gozner, M., Grama, V., Herman, G. V., Hodor, N., Hurley, P., Ilieș, A., Ilieş, D. C., Ilieș, G., Ilieş M., Josan, I., Leşe, G., Măduța, F., Mojolic, D., Morar, C., Olaru, M., Staşac, M., Stupariu, M., Sturza, A., Ştefănescu, B., Tătar, C., Vârnav, R., Vlaicu, M., \& Wendt, J. (2014). Crişana - Maramureş, Atlas Geografic al patrimoniului touristic, Editura Universităţii din Oradea.

Ilieș, D. C., Herman, G., Ilieș, A., Baias, Ș., Dehoorne, O., Buhaș, S., \& Ungureanu, M. (2017). Tourism and Biodiversity in Natura 2000 Sites. Case Study: Natura 2000 Valea Roșie (Red Valley) Site, Bihor County, Romania. Études caribéennes, (37-38).

\section{Web sources:}

https://www.frbaschet.ro/ (accessed at: 20.11.2018). 